\title{
A Gender Analysis on the Participation and Choice of Improved and Local Haricot Bean (Phaseolus vulgaris L.) by Farmers in Cameroon
}

\author{
Bella Ngoh Siri ${ }^{1,2}{ }^{*}$, Eileen Bogweh Nchanji ${ }^{3}$ (D) Isaac Roger Tchouamo² \\ ${ }^{1}$ Institute of Agricultural Research for Development (IRAD), Bambui, Cameroon \\ ${ }^{2}$ Faculty of Agronomy and Agricultural Sciences, University of Dschang, Dschang, Cameroon \\ ${ }^{3}$ International Center for Tropical Agriculture, Nairobi, Kenya \\ Email: *musibelle2000@yahoo.com
}

How to cite this paper: Siri, B.N., Nchanji, E.B. and Tchouamo, I.R. (2020) A Gender Analysis on the Participation and Choice of Improved and Local Haricot Bean (Phaseolus vulgaris L.) by Farmers in Cameroon. Agricultural Sciences, 11, 1199-1216. https://doi.org/10.4236/as.2020.1112079

Received: October 28, 2020

Accepted: December 20, 2020

Published: December 23, 2020

Copyright @ 2020 by author(s) and Scientific Research Publishing Inc. This work is licensed under the Creative Commons Attribution International License (CC BY 4.0).

http://creativecommons.org/licenses/by/4.0/

(c) (i) Open Access

\begin{abstract}
Men and women farmer participation and choice of variety could guide breeding and drive the adoption of different haricot bean varieties. Thus, understanding how gender influences participation and choice of bean cultivation and marketing is fundamental. The study sought to analyse how socio-cultural norms determine women and men, participation and choice of variety for cultivation and sale in Cameroon's West region. A mixed-method was used in collecting data from men and women farmers in six subdivisions in the West region of Cameroon in 2019. Result reveals that women provide most of the labour on haricot bean production than men, who are more involved in selling to national and regional markets. Participation and role were driven by socio-cultural norms of what is expected of men and women in a society where women provide food and men income for household upkeep. Women preferred varieties that were less labour intensive and food taste for household consumption while men went for labour intensive as long as they were market-oriented and high yielding. Thus, breeders should develop varieties that are mostly preferred by women, which meet the market and household demand.
\end{abstract}

\section{Keywords}

Gender Analysis, Participation, Improved Haricot Bean, Varieties, Choice, Cameroon

\section{Introduction}

Legumes represent an important component of agricultural food crops in de- 
veloping countries. They complement cereal crops as a source of proteins and minerals in Sub-Saharan Africa. Women in sub-Saharan Africa play a significant role in agriculture though it has been empirically impossible to verify the share produced by them [1]. They comprise an average of 43 percent of the agricultural labour force in Africa. Among the most important crops that men and women participate in are grain legumes, specifically haricot bean (Phaseolus vulgaris L.). Haricot bean plays a significant role in the diets of many households enhancing food and nutritional security, especially amongst poorer producers and consumers [2].

In Cameroon, haricot bean traditionally considered a subsistence crop is becoming more commercialised. It is now one of the most produced, traded and consumed food legumes in the country. It is increasingly being used as food in institutions (boarding schools, orphanage homes, prison yards and military camps) that feed their clienteles with haricot beans. The demand from neighbouring countries like Central African Republic, Gabon and Equatorial Guinea has also increased its value as a commercial crop leading to the introduction of fourteen improved bush, semi-climber and climbers bean varieties in 2010 and 2012; red mottled (ECAPAN 021, NUV-99, MAC 55, FEB 192), cream (TY3396-12, MAC 33, NITU), small white (MEX 142), and large white (BGG and 22-GL), yellow (KJ4/3), small red (NUV-109-2, DOR-701), small black (PNN) by Siri et al. [3]. It is a popular crop among small-scale farmers in Cameroon because it can be sown and harvested in a short period of fewer than 90 days, making it possible to have up to three seasons per year.

The crop is usually intercropped with maize, cocoyam, cassava and coffee. It is consumed together with cereals, roots/tubers, among others. Haricot bean is high in proteins, fibre, rich in vitamin (folate, thiamine, niacin), minerals (iron, zinc, calcium, potassium, magnesium) and antioxidants (selenium and carotenoids) that offer many health benefits [4]. A recent study from Pan Africa Bean Research Alliance (PABRA) shows that Cameroon has ten biofortified (high iron and zinc content) haricot bean varieties: red mottled (GLP190, MAC 33, NUA 99, FEB-192); white (MEX142, BGG); cream tripped with black (TY3396-12); cream tripped with red (MAC 55); yellow-green (KJ4/3); black (NUV-6) with the potential to contribute to physical and mental development, reduce blood disorder such as anaemia especially in women of reproductive ages, and improve immune function - a critical factor in the fight against COVID-19.

Literature suggests that when traditionally subsistence crops like cassava in Malawi and Nigeria become commercialized, gender issues emerge [5]. This can be attributed to the social norms associated with women's production of food crops and men's production of cash crops. Doss [6] ascribes this gender division of crops to women's responsibility to feed the family and men's responsibility of providing income for the household needs.

This study sets out to examine men's and women's participation in production activities and their choice of haricot bean variety. It calls for a "do no harm" 
and equitable approach, where men and women continually benefit from the commercialization of the crop at different nodes of the value chain. The rest of the paper is organized into four sections: The first section reviews literature on the gender dynamics in bean production in Cameroon, the second section details the methods used in data collection and analysis, the third section, presents the results and discussion section and the last section presents the conclusion with policy implications that foster bean production for the benefit of men and women farmers.

\section{Gender Dynamics in Haricot Bean Crop Production}

As in many Sub-Saharan countries, Cameroon's agricultural sector plays a crucial role in economic growth and poverty reduction. Cameroon's agricultural sector is one of the wealthiest and most diversified agricultural producers in Central Africa, making the country the leading food supplier accounting for 70\% of the central African regional market [7]. Cameroon is ranked the sixth in haricot bean production in Africa, and the first in Central Africa estimated at 402,054 metric tons [8]. Haricot bean is the second most frequently cultivated crop after maize in Cameroon [9]. There has been a 12.5 percent increase in haricot bean production between 2013 and 2018, possibly due to the introduction of improved varieties through the Pan Africa Bean Research Alliance project. Thus, contributing to its tremendous shift from being subsistence to a commercial crop.

Many Cameroon households rely on it for food and income to meet other needs like school fees and household assets. Gender inequalities in the economic sector hamper growth; thus, removing gender-based barriers in agriculture can substantially contribute to the Sustainable Development Goals 1 and 5 to realize agricultural growth, gender equality and reduce poverty and hunger. The Cameroonian woman has for have long been the economic backbone of the nation. In Cameroon, women's labour portion in all agricultural activities ranges from 58 to 78 percent [1]. Like Endeley [10], 88.6 percent of women constitute the active labour force in the food crop sector, producing 90 percent of total production; thus, the Cameroonian agricultural sector has a woman's face. Women and men dominate marketing at different levels. Most retail marketing is done by women, while regional and international markets by men.

Haricot bean has been considered as a women's crop in smallholder agriculture in Africa. We defined haricot bean as a woman's crop due to the number of women involved and the labour contribution towards the crop's production and marketing. Other scholars like Njuki et al. [11] have defined a woman's crop as those where women provide a significant proportion of labour, same as groundnut in Southern Africa pointed out in Takuji et al. [12]. In contrast, Doss [13], on the other hand, defines a woman's crop as one where the woman has more decision making control in the different production activities.

Traditionally women crops have been defined as crops for subsistence and 
men crops as cash crops in line with the social norms guiding women and men's activities and responsibilities. Doss [13], for example, women prepare food and men provide cash income for the family. Other studies have defined women's crops based on multiple criteria. For example, in Malawi, haricot bean is considered a woman's crop as 90 percent of the labour is provided by women, who are more knowledgeable about the crop and make most decisions on different activities to be carried out [11]. The transition of crops from subsistence to commercial will have different implications for men and women farmers, which could be positive or negative.

From a negative angle, men could continually control women's income incurred from the sale of crops as women repeatedly provide labour. Thus, taking away women's agency to make life-changing decisions on and off-farm, thus disempowering them. These scenarios can be seen in irrigated rice farming in the Gambia, where women's rights to land have been subverted, and they have been turned into hired workers [14] [15]. This is also the case of French bean in Kenya [16], hybrid maize in Zambia [17] and banana in Kenya [18].

Positively, commercialization of groundnuts in Zambia's Eastern Province [19], cassava in Malawi and Nigeria [20] and onions in Northern Ghana [21] could result in increased income and food security or not depending on who makes decisions over the sale of produce and use of the income incurred allowing for minimal risk-taking to take advantage of new opportunities. Anecdotal evidence from different case studies in East Africa shows increased productivity as women are more linked to agronomic information and training. Market activities have not changed as men still drive regional and international markets with women more involved in retail markets.

Women are moving into the distribution and marketing hubs involved in sorting and processing bean-based products. Given that we are not sure what will happen in the haricot bean sector in Central Africa, specifically in Cameroon, there is a need to understand men and women's participation and choice of haricot bean variety to have targeted interventions and make informed policies that result in an equitable share of profits from the haricot bean crop once commercialized.

Women's and men's participation in agricultural production is guided by gender division of labour based on gender roles and responsibilities. These roles and responsibilities differ by crop [21]. In most agricultural settings, weeding, winnowing, harvesting, drying of grains, storage and processing as majorly women tasks, Chayal et al. [22]. Access to productive resources like labour, land, credit, technology, fertilizers and information [11] [13] [23] [24] also influence men and women participation in different crops and agricultural activities. The distance also influences participation of men and women in agricultural production to fields, farm size, human capital, membership to groups, age, wealth index, consumption rate, colour of crop among others as cited in Alene et al. [25] [6] [26] [27]. However, it is not known whether any or most of the reasons 
above influence men and women participation or varietal choice of haricot bean production.

Even though haricot bean is considered a woman's crop in Cameroon, there is no empirical study on men and women participation in its production and choice of haricot bean variety. Given that gender disparities exist in men and women access to and control over productive activities, we will be interested in knowing if these attributes or others affect men and women participation and food security and generating income. Understanding the reason behind these differences in gendered participation would inform programmes and policies on achieving SDG 1 and 5.

This study assesses men and women participation and choice of variety in production. To meet this objective, we have two research questions: 1) What are the roles of men and women farmers in haricot bean production and marketing? 2) What factors influence women and men choice of particular haricot bean varieties?

\section{Materials and Methods}

\subsection{Study Area}

The study was carried out in Cameroon's West region in 2019, precisely in six sub-divisions-Oumbot, Kouoptamo, Bandjoun, Djebem, Nkong-Ni and Penka-Michel, identified as intensive haricot bean production zones in the West region (Figure 1). In addition, dissemination efforts of improved varieties were concentrated in these areas. This region's climate is characterised by two main seasons; the rainy season from about March to October, and the dry season from November to mid-March [28]. Most of the agricultural activities are rainfed since the region is poorly equipped with irrigation infrastructure.

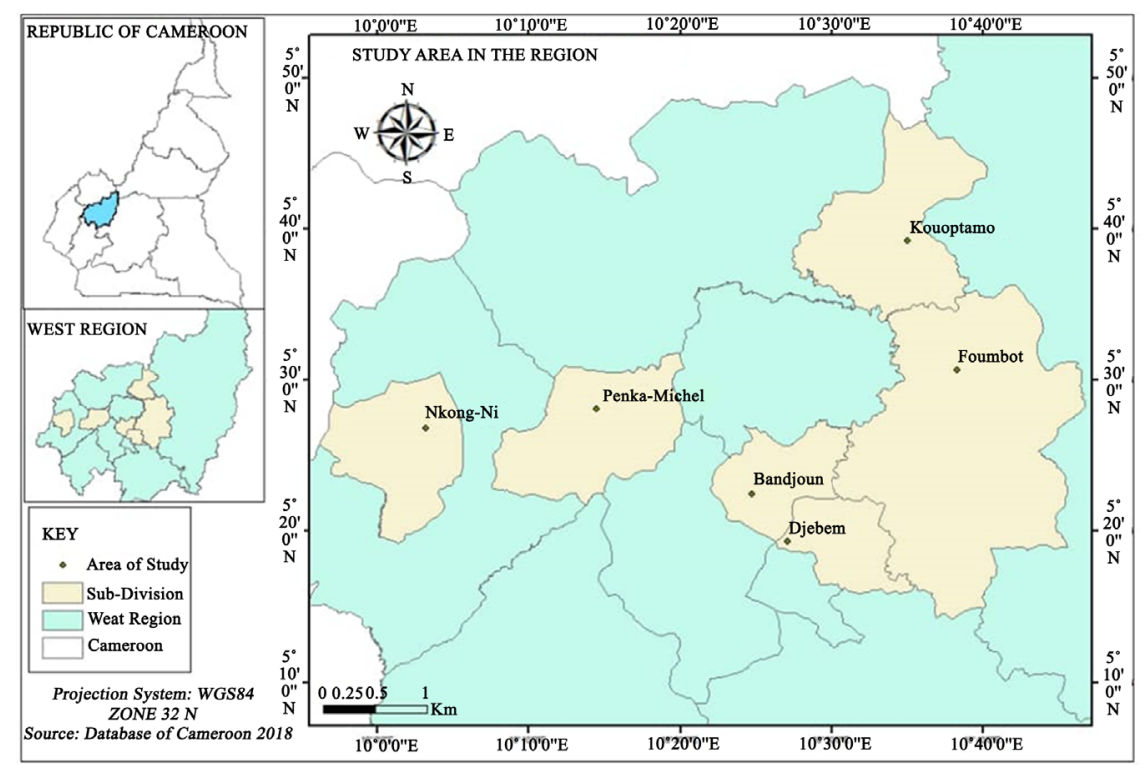

Figure 1. Study areas in the west region of Cameroon. 


\subsection{Sampling Technique}

The methodology used in this study is a multi-stage sampling procedure. In stage one, the West region was purposively selected as one of the leading haricot bean production hubs. In stage two, three administrative divisions were purposively selected-Noun, Koung-Khi and Menoua. The choice of different divisions permits the capturing of disparity in haricot bean activities by farmers. In stage three, two sub-divisions were purposively selected from each administrative division-Foumbot, Kouoptamo, Bandjoun, Djebem, Nkong-Ni and Penka-Michel, respectively. These sub-divisions were selected because their farmers benefited the most from improved seed distribution through government intervention from the Ministry of Agriculture and Rural Development (MINADER) and Ministry of Scientific Research and Innovation (MINRESI) through the delegations of Agriculture and the Agricultural Research Institute for Development (IRAD), respectively. To reduce bias and increase gender equity, two hundred and forty farmers were selected using a simple random technique from a list of farmers groups in the different sub-divisions. Thus, forty men and women farmers were selected in each division, making a total of 240 farmers in the entire study. The geographical location of respondents is presented in Table 1.

\subsection{Data Collection}

Prior to data collection, three research assistants were recruited and trained to collect data and run a pre-test before going to the field. Three visits were made to the study sites. The purpose of the first visit was to make formal arrangements for entry into the study area and established contact with key institutions and resource persons. The second visit focused on questionnaire administration to men and women haricot bean farmers. Questions were asked on socio-demographic characteristics, roles, responsibilities, participation and choice of haricot bean farming operations. In the third visit, key informant interviews were carried out with selected farmers and key resource persons from MINADER, IRAD and non-governmental organizations to validate or complement information from

Table 1. Distribution of farmers by study areas.

\begin{tabular}{|c|c|c|c|c|c|}
\hline \multirow{2}{*}{ Region } & \multirow{2}{*}{ Division } & \multirow{2}{*}{ Sub-division } & \multicolumn{2}{|c|}{ No of farmers } & \multirow{2}{*}{ Total } \\
\hline & & & Male & Female & \\
\hline \multirow{7}{*}{ West } & \multirow{2}{*}{ Noun } & Foumbot & 20 & 20 & 40 \\
\hline & & Kouoptamo & 20 & 20 & 40 \\
\hline & \multirow{2}{*}{ Koung-Khi } & Bandjoun & 20 & 20 & 40 \\
\hline & & Djebem & 20 & 20 & 40 \\
\hline & \multirow{2}{*}{ Menoua } & Nkong-Ni & 20 & 20 & 40 \\
\hline & & Penka-Michel & 20 & 20 & 40 \\
\hline & 3 & 6 & 120 & 120 & 240 \\
\hline
\end{tabular}


the survey. This was triangulated with four focus group discussions conducted in Foumbot and Penka-Michel sub-divisions with men and women farmers separately. During the Focus Group Discussion (FGD), farmers were requested to explain their choice of variety. Farms and markets were also visited in the different studied areas to get the ground-truth on why farmers preferred certain improved varieties and appreciate those that drive major markets.

\section{Results and Discussion}

\subsection{Farmers' Socio-Demographic Characteristics}

The majority of farmers are between 30 to $60+$ years, with a mean age of 42 years, as shown in Table 2. This mirrors the findings from [29] across 13 countries in three regions (Sub-Saharan Africa, Latin America, and the Caribbean

Table 2. Socio-demographic characteristics of men and women farmers.

\begin{tabular}{|c|c|c|c|}
\hline Variables & $\begin{array}{c}\text { Men } \\
\text { (percent) }\end{array}$ & $\begin{array}{l}\text { Women } \\
\text { (percent) }\end{array}$ & P-value \\
\hline \multicolumn{4}{|l|}{ Age range } \\
\hline $20-29$ & 0.0 & 0.8 & \multirow{5}{*}{0.097} \\
\hline $30-39$ & 20.8 & 29.2 & \\
\hline $40-49$ & 22.4 & 11.2 & \\
\hline $50-59$ & 28.4 & 32.1 & \\
\hline$>60$ & 28.4 & 26.7 & \\
\hline \multicolumn{4}{|l|}{ Education } \\
\hline Primary school & 24.1 & 73.5 & \multirow{4}{*}{0.000} \\
\hline Secondary school & 22.5 & 16.6 & \\
\hline High school & 33.0 & 9.1 & \\
\hline University & 20.4 & 0.8 & \\
\hline \multicolumn{4}{|l|}{ Main occupation } \\
\hline Food crop production & 21.5 & 64.5 & \multirow{4}{*}{0.000} \\
\hline Livestock farming & 51.6 & 33.5 & \\
\hline Business & 12.1 & 1.5 & \\
\hline Salary employment & 14.8 & 0.5 & \\
\hline \multicolumn{4}{|c|}{ Experience in haricot bean cultivation } \\
\hline$<10$ years & 37.4 & 0.0 & \multirow{4}{*}{0.003} \\
\hline $11-20$ years & 49.3 & 0.0 & \\
\hline 21 - 30 years & 13.3 & 47.0 & \\
\hline$>30$ years & 0.0 & 53.0 & \\
\hline \multicolumn{4}{|c|}{ Experience in improved haricot bean cultivation } \\
\hline$<2$ years & 0.8 & 0.0 & \multirow{4}{*}{0.005} \\
\hline $3-5$ years & 48.4 & 70.5 & \\
\hline $6-8$ years & 43.3 & 24.4 & \\
\hline$>8$ years & 7.5 & 5.1 & \\
\hline
\end{tabular}


and Asia-Pacific) and 38 countries from the Rural Livelihoods Information System, the average age of farmers, varies from 41 to 50 years. Interestingly, we are also seeing more young women involved in agriculture than men; that is, young women's involvement is marginally significant compared to men of the same age. This information is relevant and can guide further interventions in haricot bean production in the West region.

Findings in Table 2 also revealed that 99.2 percent of the farmers had been cultivating improved haricot bean for more than three years, indicating some experience which can permit farmers to articulate their participation level in haricot bean activities. Fifty-three percent of women farmers have more than 30 years of experience than men farmers, which is possible because women mainly do haricot bean production. The data in Table 2 further shows a lower educational level amongst women compared to men and this might be due to social norms where men education is prioritized over women leading to increased women involvement in farming than men, as pointed out also by Mugonolaa et al. [30].

Men and women's role differs depending on the type of farming activity, access, and control over the productive resource or asset. For example, we see more men involved in livestock farming while women were into crop farming. Women's involvement in crop production was significantly different by 1 percent compared to their male counterparts. The reason could be due to the gender division of labour in the farm ownership over household assets. This indicates that even though both men and women are involved in haricot bean production, most activities are done by women. With the introduction of improved varieties, more men have experience than women growing these varieties, and this is probably due to the risk involved in investing in any new technology, but we are seeing an increasing surge of women-70.5 percent-growing improved varieties within 3 to 7 years. During FGD, most farmers in Foumbot said they had cultivated these varieties for more than eight years due to their proximity to the mother station, where seed multiplication of these varieties is done. Thus, proximity and availability also increase years of experience in cultivating these improved varieties.

\subsection{Do Men and Women Participate Equally in Haricot Bean Production?}

Women and men play different roles in improved bean production and marketing guided by gender division of labour and socio-cultural norms within the household and community. Figure 2 shows us that in our study site, men and women are involved in all farming operations from production to marketing, but their degree of participation differs. For example, women were more involved in ridging (43.7 percent), seed selection (36.6 percent), planting (50.4 percent), fertiliser application (27.9 percent), sorting (44.1 percent), and storage (42.5 percent). Women and children were also more involved in land preparation 


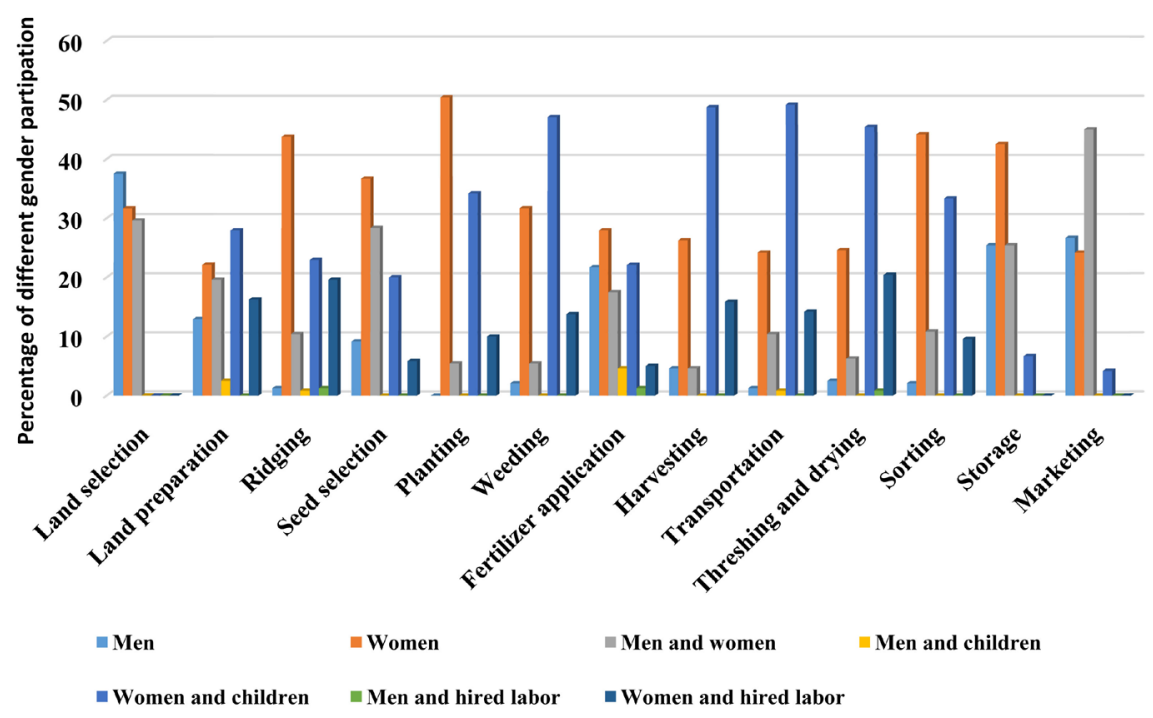

Figure 2. Gender participation in haricot bean farming and marketing operations.

(27.9 percent), weeding (47.1 percent), harvesting (48.7 percent), transportation from farm to the homestead (49.2 percent), threshing and drying (45.4 percent).

In activities performed by women and children, men's participation was very low, less than 5 percent or non-existent when it came to weeding, harvesting, transportation, threshing, and drying. Men were utterly absent in weeding but more present in land selection (37.5 percent), even though 31.6 percent of women also took part in land selection. Men and women were both more involved in marketing (45 percent), with men (26.6 percent) slightly more than women (24.1 percent) participating in this activity. During FGDs, men farmers agreed that women contribute the most in haricot bean farming operations, compared to them, despite their domestic duties. A male farmer expressed that men are known to spend time with friends, either drinking or relaxing, while women handled most farming operations before marketing.

Thus, in Cameroon's West region, women provide a greater share of labour compared to their male counterparts. This is probably because haricot bean production is dominated by women across many developing countries [13] [23]. This also ties in nicely with [30] that women's participation in Africa's agriculture is massive via providing labour for different agricultural activities. Women provision of labour is also tied to their societal expectation, as reiterated by women in the FGDs when they said that they spend more time in farming activities than the men because they have the responsibility of fulfilling their domestic duties while the men engage in other white colour jobs that bring income to the household.

Our findings revealed children's participation in almost all farm activities, especially with their mothers. This implies that children's participation in agriculture is thus beneficial to women in rural areas, as seen in their contribution to the majority of the labour in haricot bean operations. Chayal et al. [23] and [22] 
highlighted planting, weeding, harvesting, drying, and storage as predominantly female activities. These findings give a clear indication that haricot bean production has a woman's face despite men's interest in the crop [31] [32]. However, the men were visible in land selection, and their visibility in this activity reflects the fact that they have more land rights than the women, who are often only granted user/access rights accompanied by restrictive clauses on what should be grown [33] [34].

Traditional activities (land preparation and fertilizer application) earlier considered and reserved exclusively for men due to the technical knowledge and manpower are being carried out mainly by women. These findings contradict a study carried out by Akter et al. [35]. Who found out that men dominated activities with high energy requirements or technical know-how. Variation in men and women participation could be attributed to access and control over resources such as labour and land and other input such as credit, seeds, fertilizer and information [11] [23] [24].

Women worked with hired labour in all activities except when it came to storage and marketing. On the other hand, men got assistance from hired labour for land preparation, ridging, fertilizer application, and transportation. As gathered during the focus group discussion with women, a greater percentage of hired labour used in threshing and winnowing the crop are men. This might be because these activities involved more strength compared to other types of labour activities.

\subsection{How Gender Affects a Farmer's Choice of Different Improved Varieties}

Farmers in Cameroon grow different haricot bean varieties, with some varieties preferred more by men or women. In Figure 3, we see that men and women farmers both grow fourteen of the improved varieties in varying degrees, with men only growing KJ4/3 (climber) variety. Men have a higher preference for

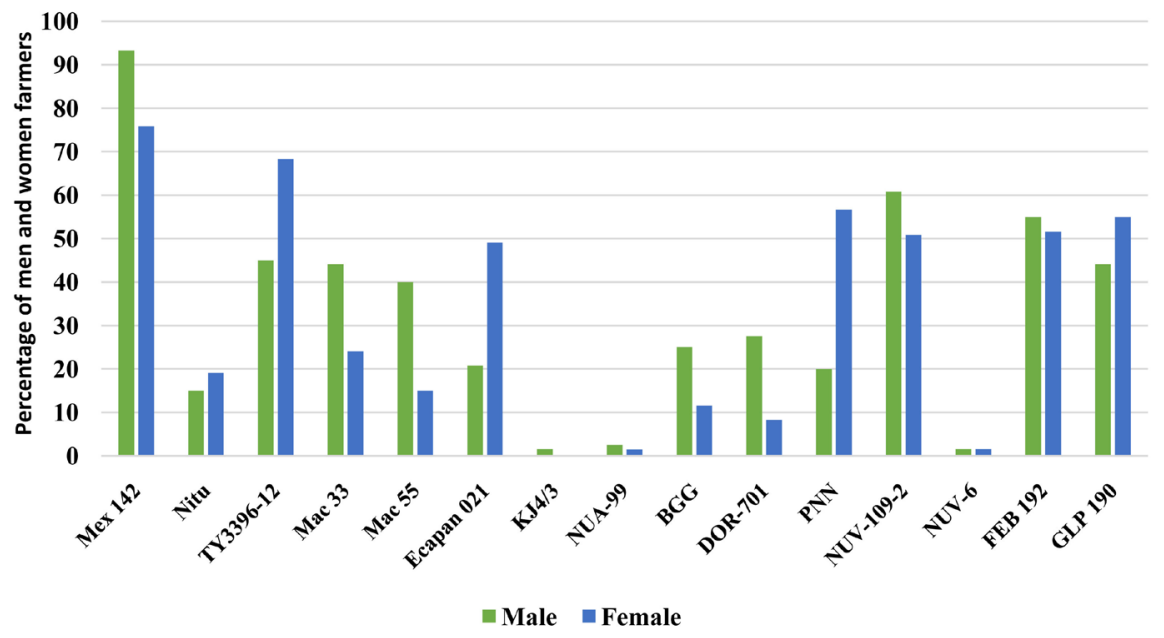

Figure 3. Men and women farmer varietal preferences. 
MEX 142 (climber), BGG (bush), MAC 55 (climber), NUA 99 (bush), FEB192 (bush), NUV-109-2 (climber), DOR-701 (climber); compared to women who have a higher preference for NITU (bush), TY3396-12 (semi-climber), ECAPAN 021 (bush), GLP190 (bush) and PNN (bush). Women and men, preference for NUV 6 (climber) were the same.

The difference in choices of variety by gender is probably linked to the division of labour between men and women. Men are growing more climbers than women, and this could be because of the labour involved. Climbers usually provide twice the yield of bush haricot bean, so men's involvement could be ascribed to their social role of providing income for the household and women's food for consumption. To have a clearer picture of men and women's choice of improved haricot varieties, we asked men and women farmers to rank the best four varieties, as shown in Table 3. Men and women ranked varieties differently. There were statistically significant differences in the ranking of the variety by sex, as indicated by significant $P$-values ( $P$ is less than 0.001 ). Men and women farmers both preferred MEX 142 and FEB 192, while men chose NUV-109-2 and GLP 190 and women ECAPAN 021 and PNN.

Ninety percent of men farmers preferred MEX 142, which is a climber compared to 26.6 percent of women, while 72 percent of women preferred FEB 192, a bush compared to 70 percent of men. We see men's shift towards higher yields and markets compared to women's shift towards home consumption. This can be attributed to the different markets targeted by men and women due to socio-cultural norms explained in focus group discussions (FGD) by men and women farmers.

While women sell in local markets as retailers, we were informed that men sell in national markets and export their haricot bean to regional markets. This information was reiterated in key informant interviews with farmers and resource persons in the field. We were told that men's preference for MEX 142 and

Table 3. Distribution of farmers on most cultivated improved haricot bean varieties by sex.

\begin{tabular}{|c|c|c|c|c|c|c|c|c|}
\hline \multicolumn{4}{|c|}{$\begin{array}{c}\text { Most cultivated } \\
\text { improved varieties for men }\end{array}$} & \multicolumn{4}{|c|}{$\begin{array}{l}\text { Most cultivated } \\
\text { improved varieties for women }\end{array}$} & \multirow{3}{*}{$\chi^{2}$ value } \\
\hline \multirow{2}{*}{ Rank } & \multirow{2}{*}{ Varieties } & \multicolumn{2}{|c|}{ Men } & \multirow{2}{*}{ Rank } & \multirow{2}{*}{ Varieties } & \multicolumn{2}{|c|}{ Women } & \\
\hline & & $\mathrm{n}$ & percent & & & $\mathrm{n}$ & percent & \\
\hline $1^{\text {st }}$ & MEX 142 & 108 & 90.00 & $1^{\text {st }}$ & FEB 192 & 72 & 60.00 & $\begin{array}{c}\chi^{2}=184.7587 \\
P=0.000\end{array}$ \\
\hline $2^{\text {nd }}$ & NUV-109-2 & 92 & 76.67 & $2^{\text {nd }}$ & PNN & 45 & 37.50 & $\begin{array}{c}\chi^{2}=132.9298 \\
P=0.000\end{array}$ \\
\hline $3^{\text {rd }}$ & FEB 192 & 70 & 58.33 & $3^{\text {rd }}$ & $\begin{array}{c}\text { ECAPAN } \\
021\end{array}$ & 34 & 28.33 & $\begin{array}{c}\chi^{2}=102.1606 \\
P=0.000\end{array}$ \\
\hline $4^{\text {th }}$ & GLP 190 & 48 & 40.00 & $4^{\text {th }}$ & Mex 142 & 32 & 26.67 & $\begin{array}{c}\chi^{2}=67.6878 \\
P=0.000\end{array}$ \\
\hline
\end{tabular}


NUV-109-2 resulted from its high yielding potential, high cash return, and acceptability in both the national and external markets. For example, in the 2019/2020 season, $100 \mathrm{~kg}$ of MEX 142 was sold at $\$ 190$ while $100 \mathrm{~kg}$ of NUV-109-2 was sold at \$130.2 in urban towns compared to FEB 192 and PNN sold at $\$ 108.5$ and $\$ 81.2$, respectively. From the men, FGD, climbers such as MEX 142 are suitable where land is a limiting factor, as the bean climb upwards and do not take up a lot of surface area. They added that besides MEX 142, other varieties such as NUV-109-2, GLP 190, and FEB 192 are among haricot bean types exported to neighbouring countries. A male farmer in Kouoptamo said:

"I also cultivate climbing and bush varieties such as FEB 192 and GLP 190 respectively due to their early maturing characteristics and also because they are highly demanded both in local and international markets."

Women highlighted during FGD that they preferred bush varieties to climbers because it is less labour intensive. For example, in the September season, you can weed once when growing bush bean types but about three times with climbers, which takes a longer time to mature. It was also gathered from women that the bush varieties could easily be intercropped with other crops (maize, cocoyam, and cassava) during the March/April season cultivation due to its compatibility. Women's choice for crops that require less labour could be due to the triple burden (reproduction, production, and community managing roles). With more time, women could do more productive activities, generating more income for households.

In addition to less labour in the cultivation of bush varieties, women argued that FEB 192 and PNN are more tasteful and mature early (75 to 80 days compared to 90 days) than MEX 142 and NUV-109-2, which makes it a food security net crop during the month of May and June when other crops such as maize and tubers (cocoyam and potatoes) are still in the field and not yet matured to be consumed as food.

Furthermore, some women said:

"We are not ready to grow climbers on our plots because it needs greater cash investments (provided by our spouses) such as fertilizer, pesticides, and staking materials."

Another said:

"I only grow MEX 142 as a joint crop with my spouse because it is mainly for the market, and he provides the necessary inputs."

In general, this study's findings show that women perceive the production of climbing improved varieties as more time-consuming and labour intensive than bush varieties that are easy to cultivate and have a favourable taste. At the same time, men prefer varieties that are market-oriented with high yielding potentials. Overall, it was observed that gender differences such as maturity, crop yield, market acceptability, the need for cash and food defined the choice of haricot bean variety. 
Even though farmers are aware of the added advantages of cultivating improved haricot bean, they still cultivate local varieties that have characteristics they appreciate, such as taste, grain colour, size, and market acceptability. Local varieties are also preferred due to the availability of seeds, which can be saved, easily be gotten from other farmers, and bought from the market. We asked men and women farmers to rank their four best local haricot bean varieties. Men and women all selected the same local varieties in different orders, as shown in Table 4.

A greater proportion of the farmers still cultivate Black varieties (97.5 percent), followed by Merengue ( 92.5 percent), long red grain ( 80.8 percent), and Senegalese (56.6 percent). While many more farmers cultivate these varieties, 28.0 percent of farmers said they had abandoned local varieties mostly because of late maturity, low yield potentials, susceptibility to diseases, and high input requirements. A greater proportion of men farmers ranked Merengue and Senegalese while women did so for the Black variety and Merengue in the first and second positions, respectively. While women rank the Black varieties in the first position because of its favourable taste and also because consumers like it, the men did so in the fourth position. This explains the high cultivation of the improved PNN variety, which has similar traits to the local Black variety by women farmers compared to the men. In the men farmers, FGD, men who ranked Merengue in the first position, said they did so due to its high yielding potentials, attractive colour, and also because the regional markets highly demand it. This further explains the high cultivation of NUV-109-2 improved variety whose traits characters are very similar to Merengue. For these reasons, farmers and traders have named it the new Merengue. As expressed by women farmers during FGD, the choice of varieties planted depends on their use, either for food or income. Hence, the breeding and promotion of improved or local haricot bean varieties should consider gender differences between men and women farmers.

Table 4. Distribution of farmers on most cultivated traditional haricot bean varieties by sex.

\begin{tabular}{|c|c|c|c|c|c|c|c|c|}
\hline \multicolumn{4}{|c|}{$\begin{array}{l}\text { Most cultivated } \\
\text { traditional varieties for men }\end{array}$} & \multicolumn{4}{|c|}{$\begin{array}{l}\text { Most cultivated } \\
\text { traditional varieties for women }\end{array}$} & \multirow{3}{*}{$\chi^{2}$ value } \\
\hline \multirow{2}{*}{ Rank } & \multirow{2}{*}{ Varieties } & \multicolumn{2}{|c|}{ Men } & \multirow{2}{*}{ Rank } & \multirow{2}{*}{ Varieties } & \multicolumn{2}{|c|}{ Women } & \\
\hline & & $\mathbf{n}$ & percent & & & $\mathrm{n}$ & percent & \\
\hline $1^{\text {st }}$ & Merengue & 119 & 99.17 & $1^{\text {st }}$ & Black & 120 & 100.00 & $\begin{array}{l}\chi^{2}=15.4032 \\
P=0.000\end{array}$ \\
\hline $2^{\text {nd }}$ & Senegalese & 77 & 64.17 & $2^{\text {nd }}$ & Merengue & 103 & 85.83 & $\begin{array}{c}\chi^{2}=72.8036 \\
P=0.000\end{array}$ \\
\hline $3^{\text {rd }}$ & $\begin{array}{l}\text { Long red } \\
\text { grain }\end{array}$ & 101 & 84.17 & $3^{\text {rd }}$ & $\begin{array}{l}\text { Long red } \\
\text { grain }\end{array}$ & 93 & 77.50 & $\begin{array}{l}\chi^{2}=26.2918 \\
P=0.000\end{array}$ \\
\hline $4^{\text {th }}$ & Black & 114 & 95.00 & $4^{\text {th }}$ & Senegalese & 59 & 49.17 & $\begin{array}{c}\chi^{2}=6.1538 \\
P=0.046\end{array}$ \\
\hline
\end{tabular}




\subsection{Gender Participation in Improved Haricot Bean Marketing}

Farmers were requested to rank their four best varieties in relation to the market demand. The findings showed that all the market varieties such as MEX 142, NUV-109-2, FEB 192, ECAPAN 021, and PNN, as shown in Table 5, are cultivated by men and women farmers as shown in Table 3. Therefore, it is logical to conclude that farmers cultivate mostly improved varieties accepted in the market, as haricot bean becomes commercialised. Statistical differences were noticed for MEX 142, NUV-109-2 and FEB 192, ECAPAN 021, and PNN as a greater proportion of men marketed these varieties than women. Conversely, this trend was not the same with PNN as men and women rated it almost equally (Table 5).

Doss [13] attributed these discrepancies to the fact that men are often viewed as being responsible for producing cash crops while women are accountable for producing subsistence crops for home consumption and only sell the surplus in the market. In the case of local varieties, Merengue (86.2 percent) and Senegalese (64.5 percent) were the most traded local varieties (Table 6). It is interesting to

Table 5. Distribution of farmers on most marketed improved haricot bean varieties by sex.

\begin{tabular}{|c|c|c|c|c|c|c|c|c|}
\hline \multicolumn{4}{|c|}{$\begin{array}{l}\text { Most marketed } \\
\text { improved varieties for men }\end{array}$} & \multicolumn{4}{|c|}{$\begin{array}{l}\text { Most marketed } \\
\text { improved varieties for women }\end{array}$} & \multirow{3}{*}{$\chi^{2}$ value } \\
\hline \multirow{2}{*}{ Rank } & \multirow{2}{*}{ Varieties } & \multicolumn{2}{|c|}{ Men } & \multirow{2}{*}{ Rank } & \multirow{2}{*}{ Varieties } & \multicolumn{2}{|c|}{ Women } & \\
\hline & & $\mathbf{n}$ & percent & & & $\mathrm{n}$ & percent & \\
\hline $1^{\text {st }}$ & MEX 142 & 106 & 88.33 & $1^{\text {st }}$ & FEB 192 & 46 & 38.33 & $\begin{array}{c}\chi^{2}=69.9874 \\
\mathrm{P}=0.000\end{array}$ \\
\hline $2^{\text {nd }}$ & NUV-109-2 & 90 & 75.00 & $2^{\text {nd }}$ & MEX 142 & 30 & 25.00 & $\begin{array}{l}\chi^{2}=78.6756 \\
P=0.000\end{array}$ \\
\hline $3^{\text {rd }}$ & FEB 192 & 93 & 77.50 & $3^{\mathrm{rd}}$ & $\begin{array}{c}\text { ECAPAN } \\
021\end{array}$ & 42 & 35.00 & $\begin{array}{c}\chi^{2}=95.2998 \\
P=0.000\end{array}$ \\
\hline $4^{\text {th }}$ & PNN & 120 & 100 & $4^{\text {th }}$ & PNN & 114 & 95.00 & $\begin{array}{c}\chi^{2}=6.1538 \\
P=0.104\end{array}$ \\
\hline
\end{tabular}

Table 6. Distribution of farmers on most marketed traditional haricot bean varieties by sex.

\begin{tabular}{|c|c|c|c|c|c|c|c|c|}
\hline \multicolumn{4}{|c|}{$\begin{array}{c}\text { Most Marketed } \\
\text { traditional varieties for men }\end{array}$} & \multicolumn{4}{|c|}{$\begin{array}{c}\text { Most marketed } \\
\text { traditional varieties for women }\end{array}$} & \multirow{3}{*}{$\chi^{2}$ value } \\
\hline \multirow{2}{*}{ Rank } & \multirow{2}{*}{ Varieties } & \multicolumn{2}{|c|}{ Men } & \multirow{2}{*}{ Rank } & \multirow{2}{*}{ Varieties } & \multicolumn{2}{|c|}{ Women } & \\
\hline & & $\mathrm{n}$ & percent & & & $\mathrm{n}$ & percent & \\
\hline $1^{\text {st }}$ & Merengue & 119 & 99.17 & $1^{\text {st }}$ & Merengue & 88 & 73.33 & $\begin{array}{c}\chi^{2}=33.7964 \\
P=0.000\end{array}$ \\
\hline $2^{\text {nd }}$ & Senegalese & 77 & 64.17 & $2^{\text {nd }}$ & Senegalese & 78 & 65.00 & $\begin{array}{c}\chi^{2}=49.0293 \\
P=0.000\end{array}$ \\
\hline $3^{\text {rd }}$ & $\begin{array}{l}\text { Long red } \\
\text { grain }\end{array}$ & 109 & 90.83 & $3^{\text {rd }}$ & $\begin{array}{l}\text { Long red } \\
\text { grain }\end{array}$ & 116 & 96.67 & $\begin{array}{l}\chi^{2}=11.2178 \\
P=0.011\end{array}$ \\
\hline $4^{\text {th }}$ & Black & 114 & 95.00 & $4^{\text {th }}$ & Black & 120 & 100 & $\begin{array}{c}\chi^{2}=6.1538 \\
P=0.046\end{array}$ \\
\hline
\end{tabular}


note that even though the Black variety ranked the most amongst cultivated varieties, especially by women, it has the least position amongst marketed varieties. Black bean is known to be the most consumed haricot bean either in porridge form with maize ("corn chaff or corn and bean stew") and pounded with Irish potatoes ("pilé" as known in the West region and "took coni" in the North West region").

\section{Conclusions}

Men's and women's participation in haricot bean production varied, with women providing most of the labour and men involved more in marketing at national and regional levels. Women were sometimes assisted by men and children but carried out most of the production activities. To reduce the time spent on the triple role women play in the household and community, women chose to grow bush bean more because they are less labour-intensive and early maturing. On the other hand, men prefer climbers because it is high yielding and uses less land area.

Interesting, men and women cultivated varieties that were demanded by the markets and the different households. With the increase in haricot bean commercialisation, men are more interested in the varieties' market acceptability to generate income and provide household needs.

Therefore, breeders should focus on developing bush varieties that attract women farmers since they form a larger proportion of haricot bean farmers. Meanwhile, it should be noted that mere sensitization about improved haricot bean varieties will not translate to the adoption of the varieties unless easy access to seeds and farmers' choices are taken into consideration.

\section{Acknowledgements}

This paper is part of the doctoral thesis of the first author. We are indebted to the farmers and key informants who provided their time for this research. The authors also thank the anonymous reviewers for their valuable comments.

\section{Conflicts of Interest}

The authors declare no conflicts of interest regarding the publication of this paper.

\section{Funding}

This paper was funded by the Consultative Group for International Agricultural Research (CGIAR) Generating Evidence and New Directions for Equitable Results (GENDER) Platform. The CGIAR's Gender Platform is a new platform designed to put gender equality at the forefront of global agricul-tural research for development and transform the way gender research is done within and beyond the CGIAR. ILRI GENDER Platform Window 1/Window 2 Grant. 


\section{References}

[1] Food and Agriculture Organization (2011) The State of Food and Agriculture: Women in Agriculture: Closing the Gender Gap for Development. Food and Agriculture Organization, Rome.

[2] Kebede, E. (2020) Grain Legumes Production and Productivity in Ethiopian Smallholder Agricultural System, Contribution to Livelihoods and the Way Forward. Cogent Food \& Agriculture, 6, Article ID: 1722353. https://doi.org/10.1080/23311932.2020.1722353

[3] Siri, B.N., Etchu, K.A., Manka, S.N., Emoh, S.B., Atemkeng, M.F and Nounamo, L. (2016) Assesing Preference of Released Improved Haricot Beans (Phaseolus vulgaris L.) by Farmers in the Western Highlands of Cameroon. International Journal of Development Research, 6, 8317-8322.

[4] Buruchara, R., Chirwa, R., Sperling, L., Sperling, L., Mukankusi, C., Rubyogo, J.C., et al. (2011) Development and Delivery of Bean Varieties in Africa: The Pan-Africa Bean Research Alliance (PABRA) Model. African Crop Science Journal, 19, 227-245.

[5] Nakazi, F., Njuki, J., Ugen, M.A., Aseete, P., Katungi, E., Birachi, E., et al. (2017) Is bean Really a Women's Crop? Men and Women's Participation in Bean Production in Uganda. Agriculture \& Food Security, 6, Article No. 22. https://doi.org/10.1186/s40066-017-0102-Z

[6] Paudel Khatiwada, S., Deng, W., Paudel, B., Khatiwada, J.R., Zhang, J. and Wan, J. (2018) A Gender Analysis of Changing Livelihood Activities in the Rural Areas of Central Nepal. Sustainability, 10, 4034. https://doi.org/10.3390/su10114034

[7] World Bank Group (2018) Breaking Down the Barriers to Regional Agricultural Trade in Central Africa. World Bank, Washington DC.

https://openknowledge.worldbank.org/handle/10986/30397

[8] Food and Agriculture Organization (2020) Statistics 2020. http://www.fao.org/faostat/en/\#compare

[9] Haggblade, S. and Dewina, R. (2010) Staple Food Prices in Uganda. Prepared for the Comesa Policy Seminar on "Variation in Staple Food Prices. Causes, Consequence, and Policy Options”, Maputo, 25-26 January 2010, 1-15. https://doi.org/10.22004/AG.ECON.58553

[10] Endeley. J.B. (1989) Strategies and Programs for women in Agricultural Sector in Africa. In: Von Braunmuuuhl, C., Ed., Women in the Development Process, DSE, Berlin, 29-42.

[11] Njuki, J., Kaaria, S., Chamunorwa, A. and Chiuri, W. (2011) Linking Smallholder Farmers to Markets, Gender and Intra-Household Dynamics: Does the Choice of Commodity Matter? The European Journal of Development Research, 23, 426-443. https://doi.org/10.1057/ejdr.2011.8

[12] Takuji, W.T., Harry, W.M., Moses, S., Kizito, M. and Patrick, O. (2016) Evolution and Impacts of Groundnut Research and Development in Malawi: An Ex-Post Analysis. African Journal of Agricultural Research, 11, 139-158. https://doi.org/10.5897/AJAR2015.10167

[13] Doss, C.R. (2001) Designing Agricultural Technology for African Women Farmers: Lessons from 25 Years of Experience. World Development, 29, 2075-2095. https://doi.org/10.1016/S0305-750X(01)00088-2

[14] Carney, J. and Watts, M. (1990) Manufacturing Dissent: Work, Gender and the Politics of Meaning in a Peasant Society. Africa, 60, 207-241. 
https://doi.org/10.2307/1160333

[15] Carney, J. and Watts, M. (1991) Disciplining Women? Rice, Mechanization, and the Evolution of Mandinka Gender Relations in Senegambia. Signs. Journal of Women in Culture and Society, 16, 651-681. https://doi.org/10.1086/494698

[16] Dolan, C. (2001) The 'Good Wife': Struggles over Resources in the Kenyan Horticultural Sector. The Journal of Development Studies, 37, 39-70. https://doi.org/10.1080/00220380412331321961

[17] Kumar, S.K. (1994) Adoption of Hybrid Maize in Zambia: Effects on Gender Roles, Food Consumption, and Nutrition. Research Report No. 100, International Food Policy Research Institute, Washington DC.

[18] Fischer, E. and Qaim, M. (2012) Linking Smallholders to Markets: Determinants and Impacts of Farmer Collective Action in Kenya. World Development, 40, 1255-1268. https://doi.org/10.1016/j.worlddev.2011.11.018

[19] Orr, A., Tsusaka, T., Kee-Tui, S.H. and Msere, H. (2016) What Do We Mean by 'Women's Crops'? Commercialisation, Gender and the Power to Name. Journal of International Development, 28, 919-937. https://doi.org/10.1002/jid.3224

[20] Forsythe, L., Posthummus, H. and Martin, A. (2016) A Crop of One's Own? Women's Experiences of Cassava Commercialization in Nigeria and Malawi. Journal of Gender, Agriculture and Food Security, 1, 110-128.

[21] Padmanabhanan, M.A. (2004) The Making and Unmaking of Gendered Crops in Northern Ghana. Paper Presented at Conference on International Agricultural Research for Development, Berlin, 5-7 October 2004, 21.

[22] Chayal, K., Dhaka, B.L. and Suwalka, R.L. (2010) Analysis of Role Performed by Women in Agriculture. Humanity and Social Sciences Journal, 5, 68-72.

[23] Carr, E.R. (2008) Men's Crops and Women's Crops: The Importance of Gender to the Understanding of Agricultural and Development Outcomes in Ghana's Central Region. World Development, 36, 900-915. https://doi.org/10.1016/j.worlddev.2007.05.009

[24] Emeya, S. (2014) Role of Women in Agricultural Activities in Abua-Odual Local Government Area of Rivers State, Nigeria. World Rural Observations, 6, 1-6.

[25] Alene, A.D., Manyong, V.M., Omanya, G., Mignouna, H.D., Bokanga, M. and Odhiambo, G. (2008) Smallholder Market Participation under Transactions Costs: Maize Supply and Fertilizer Demand in Kenya. Food Policy, 33, 318-328. https://doi.org/10.1016/j.foodpol.2007.12.001

[26] Nakazi, F. and Sserunkuuma, D. (2013) Factors Affecting the Decision and Extent of Rice-Milling before Sale among Ugandan Farmers. Asian Journal of Agriculture and Rural Development, 3, 576-583. http://dx.doi.org/10.22004/ag.econ.198235

[27] Bellemare, M.F. and Barrett, C.B. (2006) An Ordered Tobit Model of Market Participation: Evidence from Kenya and Ethiopia. American Journal of Agricultural Economics, 88, 324-337. https://doi.org/10.1111/j.1467-8276.2006.00861.x

[28] Yengoh, G.T. (2012) Determinants of Yield Differences in Small-Scale Food Crop Farming Systems in Cameroon. Agriculture \& Food Security, 1, Article No. 19.

[29] Aslihan, A. (2019) How Old Is the Average Farmer in Today's Developing World? https://www.ifad.org/en/web/latest/blog/asset/41207683

[30] Mugonolaa, B., Deckersa, J., Poesena, J., Isabiryec, M. and Mathijsa, E. (2013) Adoption of Soil and Water Conservation Technologies in the Rwizi Catchment of South Western Uganda. International Journal of Agricultural Sustainability, 11, 
264-281. https://doi.org/10.1080/14735903.2012.744906

[31] Klapper, L.F. and Parker, S.C. (2011) Gender and the Business Environment for New Firm Creation. World Bank Research Observer, 26, 237-257.

https://doi.org/10.1093/wbro/lkp032

[32] Siri, B.N., Tchouamo, I.R. and Nchanji, E.B. (2020) Gender Analysis of Farmers' Perception of Improved Haricot Bean (Phaseolus vulgaris L.) Varieties in the West Region of Cameroon. International Journal of Agricultural Policy and Research, 8, 107-115.

[33] Nchanji, E.B. (2017) The Piper Calls the Tune: Changing Roles of Northern Ghanaian Women in Agriculture. Agriculture for Development, 32.

[34] Nchanji, E.B. and Bellwood-Howard, I. (2016) Traditional Provisioning Responsibilities of Women in Northern Ghana. In: Segal, M.T. and Demos, V.P., Eds., Gender and Food: From Production to Consumption and After, Emerald Group Publishing Limited, London, 41-64.

https://doi.org/10.1108/S1529-212620160000022013

[35] Akter, S., Rutsaert, P., Luis, J., Htwe, N.M., San, S.S., Raharjo, B. and Pustika, A. (2017) Women's Empowerment and Gender Equity in Agriculture: A Different Perspective from Southeast Asia. Food Policy, 69, 270-279.

https://doi.org/10.1016/j.foodpol.2017.05.003 